\title{
Rekayasa Model Perencanaan Transportasi dalam Menciptakan Mobilitas yang Aman pada Masa Pandemi Covid 19 (Studi Kasus : Mobilitas Mahasiswa di Jawa Timur)
}

\author{
Engineering Transportation Planning Model in Creating Safe Mobility During the Covid-19 Pandemic \\ (Case Study: Student Mobility in East Java)
}

\author{
Alfiatus Aisyah Nurhidayah ${ }^{{ }^{*},}$, Amanda Ristriana Pattisinai ${ }^{2}$ \\ ${ }^{1,2}$ Mahasiswa Program Studi Transportasi Fakultas Teknik, Universitas Negeri Surabaya
}

\begin{tabular}{l}
\hline ARTICLE INFO \\
\hline Article history: \\
DOI: \\
10.30595/pspfs.v1i.153 \\
Submitted: \\
Maret 26, 2021 \\
Accepted: \\
June 14, 2021 \\
Published: \\
Oct 31, 2021 \\
\hline
\end{tabular}

Keywords:

Transportation Planning, Mobility, Students, Covid-19

\begin{abstract}
The mobility restriction policy imposed in response to the increasing transmission of Covid-19 brought changes in people's travel behavior, both at the global and local levels. The four traditional models at the transportation planning stage became biased because the need for travel was different during this pandemic. This study aimed to create a modification of transportation planning, where the mobility continues to use the existing four-stage transportation planning model but at the same time ensures safety from the dangers of Covid-19 transmission. The survey was conducted online on students $(\mathrm{N}=100)$ spread across cities in East Java Province, where the impact of the COVID-19 pandemic in the implementation of higher education, especially student mobility. The research findings indicated that students still travel actively to universities. The student's motive for traveling was only because of important and urgent matters dominated by work and receiving news of death from family. In contrast, the majority used private vehicles, especially on trips within the city. However, the tendency to use public transportation when traveling long distances was also still in demand by respondents.
\end{abstract}

This work is licensed under a Creative Commons Attribution 4.0 International License.

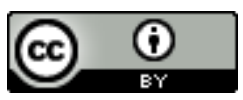

\section{Corresponding Author:}

Alfiatus Aisyah Nurhidayah

Mahasiswa Program Studi Transportasi Fakultas Teknik, Universitas Negeri Surabaya

Kampus Ketintang, Jalan Ketintang, Surabaya 60231. Telp. (031) 8280009

Email: alfiatus.19016@mhs.unesa.ac.id

\section{PENDAHULUAN}

Pandemi Covid-19 membawa dampak perubahan yang cukup signifikan dalam kegiatan bertransportasi masyarakat (Padmanabhan, 2021; Bian, 2021; Katrakazas, 2020). Empat model tradisional pada tahapan perencanaan transportasi (Ahmed, 2012; Agrawal, 2018, Kadiyali, 2004), yang dimulai dari perencanaan trip generation, trip distribution, moda split, hingga trip assigment; menjadi bias penggunaannya karena kebutuhan akan perjalanan menjadi berbeda saat pandemi ini.

Kebijakan pembatasan mobilitas yang diberlakukan sebagai tanggapan terhadap meningkatnya penularan Covid19 membawa perubahan perilaku perjalanan masyarakat, baik tingkat global maupun lokal (Politis, 2021; Engle et al., 2020). Di Indonesia, Satgas Penanganan Covid-19 memperketat pembatasan perjalanan orang di dalam negeri. Pembatasan itu tertuang dalam Surat Edaran Nomor 1 Tahun 2001 Tentang Ketentuan Perjalanan Orang Dalam Negeri Dalam Masa Pandemi Covid-19 (https://www.liputan6.com/news/read/4452765/satgas-covid-19-perketatpembatasan-perjalanan-pada-9-25-januari-2021 diakses tanggal 17 Maret 2021). Hal ini dimaksudkan untuk mencegah dan memutus rantai penyebaran Covid-19 yang berpotensi meningkat akibat perjalanan orang dari satu wilayah ke wilayah yang lain. 
Oleh karena sebab tersebut, terjadi penurunan mobilitas, di semua lokasi transit seperti stasiun, tempat kerja, ritel serta rekreasi (Pepe et al., 2020), demikian pula pada volume lalu lintas berkurang secara signifikan karena pandemi (Vingilis et al., 2020; Katrakazas et al., 2020). Dapat diartikan tahapan trip production terdampak secara signifikan terutama pada penggunaan angkutan umum di kota-kota padat penduduk (Ghosh et al., 2020); seperti penurunan ratarata penumpang kereta bawah tanah (Teixeira \& Lopes, 2020; Wang et al., 2020) dan penurunan permintaan kereta komuter (https://www.urban-transport-magazine.com/en/decline-in-ridership-adapted-timetables-and-disinfectionrobots-the-impact-of-corona-Covid-10-on-public-transport/ diakses tanggal 20 Maret 2021). Sementara itu trip distribution pada kendaraan pribadi menjadi bertambah dengan pesat, karena masyarakat mengubah pola perjalanan lokalnya menjadi transportasi pribadi pada periode pasca-pandemi (Koehl, 2020; Laverty et al., 2020).

Bersamaan dengan dampak yang mengancam nyawa masyarakat, COVID-19 secara signifikan mengubah pola perilaku bertansportasi dan mobilitas pribadi tiap individu (Vos, 2020; Bogoch et al., 2020). Sikap pribadi dan persepsi individu diketahui mempengaruhi pilihan terkait perjalanan dan pola perjalanan (Kroesen \& Chorus, 2020). Karena pengetahuan tentang penyebaran virus Covid-19 sangat terbatas, hal itu telah menimbulkan ketakutan di antara individu. Akibatnya, telah terjadi penurunan yang signifikan dalam jumlah penumpang angkutan masal cepat berorientasi transit (Park, 2020).

Wabah pandemi COVID-19 yang dimulai pada awal tahun 2020 telah secara dramatis mempengaruhi perkembangan pendidikan tinggi dalam berbagai aspek, termasuk pergeseran pengajaran tatap muka ke pengajaran dan pembelajaran online, pembatalan kegiatam dan aktivitas fisik di kampus, serta pembentukan sebuah 'normalitas baru' dalam pendidikan tinggi (Tesar, 2020). Meskipun pembelajaran online telah diperlakukan sebagai solusi untuk masalah mobilitas pada mahasiswa perguruan tinggi, siswa dan instruktur telah mengungkapkan banyak kekhawatiran negatif mengenai keefektifan pembelajaran dan interaksi selama pandemi (Xiong, 2020).

Pengaruh pandemi COVID-19 sangat luar biasa dalam penyelenggaraan pendidikan tinggi terutama mobilitas mahasiswa (Altbach \& de Wit, 2020). Karena adanya pembatasan perjalanan dan penutupan kampus, banyak mahasiswa yang mengubah atau membatalkan rencana belajar di perguruan tinggi yang berada jauh dari asal mahasiswa untuk mengurangi resiko penularan. Pada akhir 2020, Jawa Timur sempat menjadi provinsi dengan kasus Covid-19 tertinggi melebihi DKI Jakarta (https://regional.kompas.com/read/2020/09/01/07271771/sempat-jadiprovinsi-dengan-kasus-covid-19-tertinggi-bagaimana-kondisi-jatim?page=all diakses 20 Maret 2021). Walaupun saat ini kurvanya telah melandai, kondisi ini juga membuat orang tua bahkan mahasiswa merasa belum yakin dalam memutuskan bergabung dalam perguruan tinggi yang lokasinya diluar dari Propinsi Jawa Timur.

Demikian pula dengan kegiatan mahasiswa aktif selama pandemi masih melakukan mobilitas untuk kegiatankegiatan yang tidak dapat dilakukan secara online, seperti praktik laboratorium, penelitian, dan keperluan administrasi. Mobilitas ini tidak intens dilakukan namun menuntut solusi yang layak dan efisien dalam melindungi tidak hanya civitas akademia yang terlibat dalam kegiatan belajar mengajar, namun juga mencegah penularan yang masif pada masyarakat di tempat asal. Karenanya, timbul pertanyaan penelitian "Bagaimana menciptakan mobilitas orang, dimana mobilitas tersebut tetap menggunakan empat model tahapan perencanaan transportasi yang ada tetapi pada saat yang sama memastikan keselamatan dari bahaya penularan Covid-19?". Dalam artikel ilmiah ini akan dibahas mengenai modifikasi dan rekayasa perencanaan transportasi dalam keempat tahapannya, namun disesuiakan dengan protokol kesehatan serta kebijakan pemerintah dalam menyelenggarakan perjalanan yang aman selama pandemi ini.

\section{METODE PENELITIAN}

Riset rekayasa model perencanaan transportasi dalam menciptakan mobilitas yang aman pada masa pandemi covid 19, menggunakan pendekatan kuantitatif untuk mengetahui rekayasa empat model perencanaan transportasi dengan mempertimbangkan beberapa kriteria. Pendekatan empat model perencanaan transportasi digunakan dalam penelitian ini untuk dapat penilaian terhadap pilihan yang lebih luas terhadap penggunaa dan pemanfaatan yang beragam bagi mahasiswa perguruan tinggi di Propinsi Jawa Timur.

Dalam penelitian ini pengambilan sampel penelitian dilakukan dengan menggunakan metode sampling random (probability sampling). Pemilihan metode ini dianggap tepat digunakan dalam penelitian yang jumlah populasinya belum diketahui disebabkan jumlahnya yang selalu berubah-ubah setiap tahunnya (tidak stabil). Adapun jenis metode pengambilan sampel yang digunakan adalah teknik sampling area (area sampling). Teknik sampling area dianggap tepat pada populasi geografis yang tidak diketahui, dicapai dengan memperlakukan beberapa responden dalam area lokal (mahasiswa disekitaran Jawa Timur) sebagai bagian-bagian kluster sebagai sampel penelitian. Keuntungan menggunakan teknik ini ialah murah, cepat, dan mudah (Usman \& Akbar, 2008). Penelitian ini akan dibagi berdasarkan beberapa segmen penggal jalan pada Jalan Pahlawan Semarang. Penjelasan pembagian segmen penilaian persimpangan dapat dilihat pada gambar 1. 


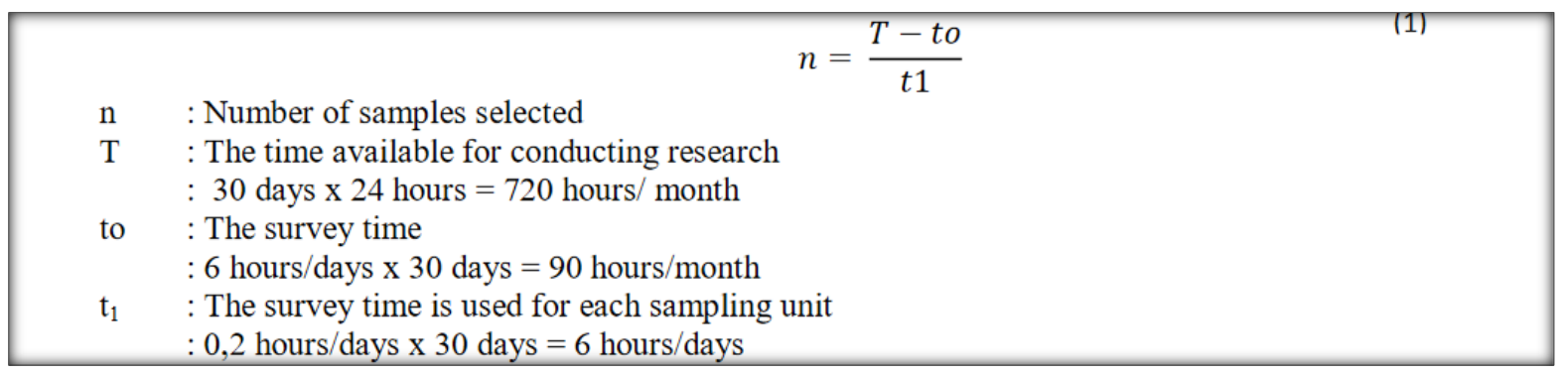

Gambar 1. Penjelasan pembagian segmen penilaian persimpangan

\section{HASIL DAN PEMBAHASAN}

Dalam mengatasi permasalahan mobilitas manusia pada saat pandemi ini, perlu adanya modifikasi dalam perencanaan suatu sistem transportasi baik jangka pendek, menengah, maupun jangka panjang. Dalam melakukan perencanaan, biasanya dilakukan dengan 4 tahapan model perencanaan sistem transportasi.

Dari 100 responden dimana 47 responden merupakan mahasiswa Universitas Negeri Surabaya dan 52 responden lainnya merupakan mahasiswa PTN/PTS yang telah survei online dengan tema "Pola Pergerakan Manusia saat Pandemi Covid-19" dimana terdapat beberapa pertanyaan diantaranya: Nama, Asal Kota, Aktivitas yang dilakukan sebelum dan sesudah pandemi, Frekuensi Pergerakan dalam kota dan luar kota, Moda transportasi yang digunakan saat bepergian dalam kota dan luar kota, Upaya pencegahan Covid-19, Alasan bepergian saat pandemi serta perasaan saat bepergian pada saat pandemi didapat hasil pengamatan yang diantaranya dapat dijabarkan pada empat model perencanaan transportasi sebagai berikut :

\section{Trip Generation}

Trip Generation atau dikenal dengan bangkitan dan tarikan perjalanan merupakan pemodelan transportasi yang berfungsi untuk memperkirakan dan meramalkan jumlah perjalanan yang berasal dari suatu zona/kawasan/petak lahan dan jumlah perjalan yang datang/tarik (menuju) ke suatu zona lahan pada masa yang akan datang (tahun rencana) per satuan waktu. Faktor yang memengaruhi bangkitan dan tarikan perjalanan antara lain :

\section{- Asal Perjalanan}

Kutela (2021) menyebutkan bahwa wabah COVID-19 telah sangat memengaruhi asal dan tujuan perjalanan manusia karena pembatasan perjalanan yang dikeluarkan pemerintah (seperti PSBB PS Mikro dan lokdown). Berdasarkan survei yang telah dilakukan, COVID-19 menunjukkan dampak yang tidak proporsional pada asal dan tujuan perjalanan responden mahasiswa; dengan Surabaya Raya masih menjadi asal pergerakan mayoritas mahasiswa. Hal ini disebabkan kegiatan belajar mengajar, walau telah ditetapkan melalui Keputusan Bersama Empat Menteri Nomor 01/KB/2020 tanggal 15 Juni 2020 tentang Panduan Penyelenggaraan Pembelajaran pada di Masa Pandemi Corona Virus Disease (Covid-19), tetap dilakukan dan sebagian besar mahasiswa masih melakukan kerja praktik serta pembimbingan saat pandemi berlangsung. Metode pembelajaran di perguruan tinggi pada semua zona wajib dilaksanakan secara daring, juga membutuhkan kestabilan jaringan internet, sehingga mayoritas responden mahasiswa memilih untuk berada didekat area kampus, disamping pilihan tidak melakukan perjalanan dan hanya berada pada daerah asal mereka yang berbatas keterjangkauan jaringan internetnya.

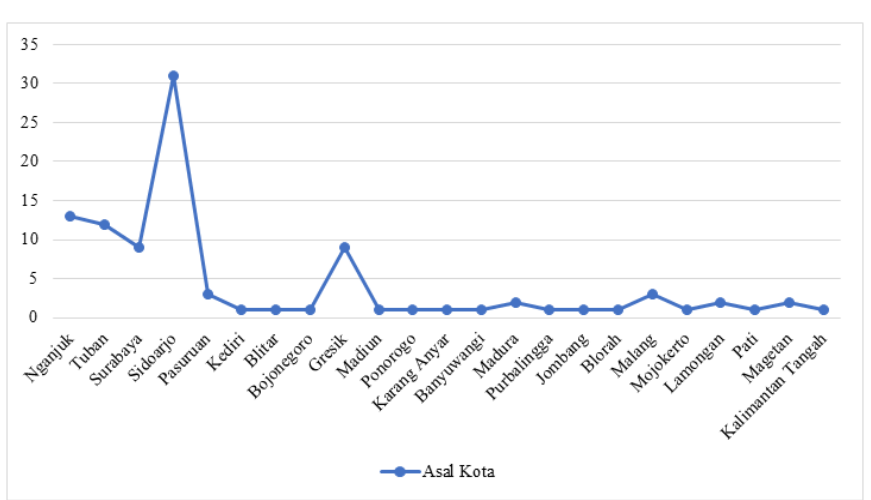

Gambar 2. Asal perjalanan mahasiswa di Propinsi Jawa Timur berdasarkan kota

\section{- Alasan melakukan mobilitas}

Temuan penelitian dari studi ini tentang alasan mahasiswa melakukan mobilitas mayoritas merupakan alasan belajar, sehingga efek negatif yang dibawa oleh pandemi COVID-19 masih membahayakan mobilitas mahasiswa yang 
sangat intens. Latar belakang mengenai mobilitas ini diakibatkan karena ketergantungan terhadap beasiswa, kegiatan kemahasiswaan, dan juga akses terhadap jaringan internet.

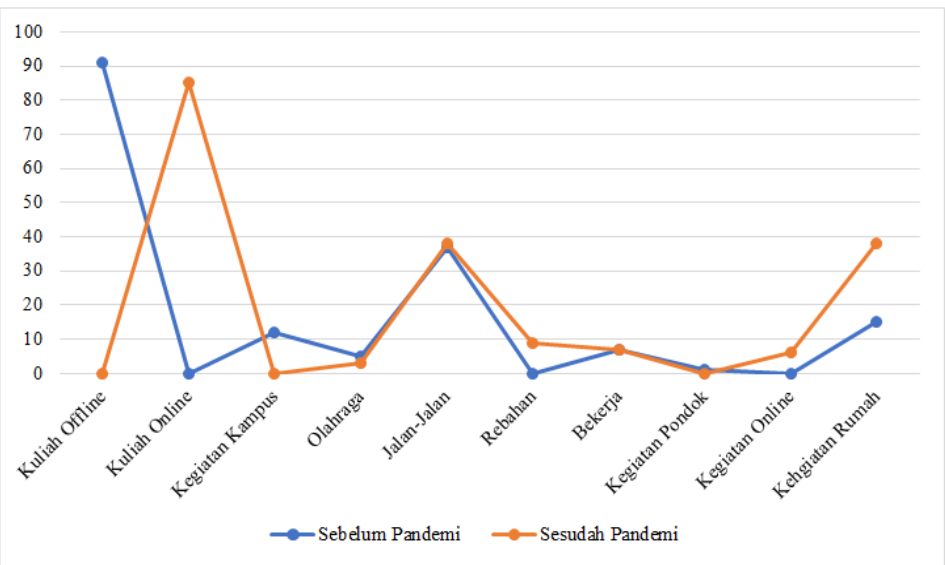

Gambar 3. Kegiatan yang mendorong mahasiswa melakukan perjalanan selama pandemi

Kebutuhan akan mobilitas dengan alasan berwisata juga menjadi mayoritas pilihan responden selama pandemi COVID-19. Kebutuhan akan kesehatan mental yang dapat diwadahi oleh kegiatan berwisata karena terlalu lama harus berada dirumah, menjadi pilihan yang signifikan sebagai alasan melakukan perjalanan. Seperti telah diisyaratkan dalam Mach (2021) bahwa mobilitas dengan tujuan pariwisata dilakukan oleh wisatawan dengan rentang usia yang lebih muda, lebih berani, dan tahan krisis; tujuanbepergian akan sangat selektif, misal ke tujuan wisata terpencil yang jarang penduduknya yang menawarkan pembatasan sosial yang menghindarkan dari bahaya tertular virus ini (Hall, 2020).

\section{Trip Distribution}

Trip distribution adalah pemodelan untuk melihat bagaimana lalu lintas dapat ditimbulkan oleh suatu wilayah itu didistribusikan. Apakah arah pejalanan itu semua menuju satu tempat atau tersebar merata. Faktor yang menentukan Trip Distribution adalah jumlah perjalanan itu sendiri yang berupa orang, kendaraan, maupun barang yang terjadi di antar zona. Sementara itu, pandemi COVID-19 telah mengurangi frekuensi perjalanan masyarakat dalam berbagai cara, terutama pada rumah tangga berpenghasilan rendah (Basu, 2021). Mahasiswa yang dapat dikategorikan sebagai mayoritas berpenghasilan rendah atau belum berpenghasilan juga mendapatkan dampak tersebut.

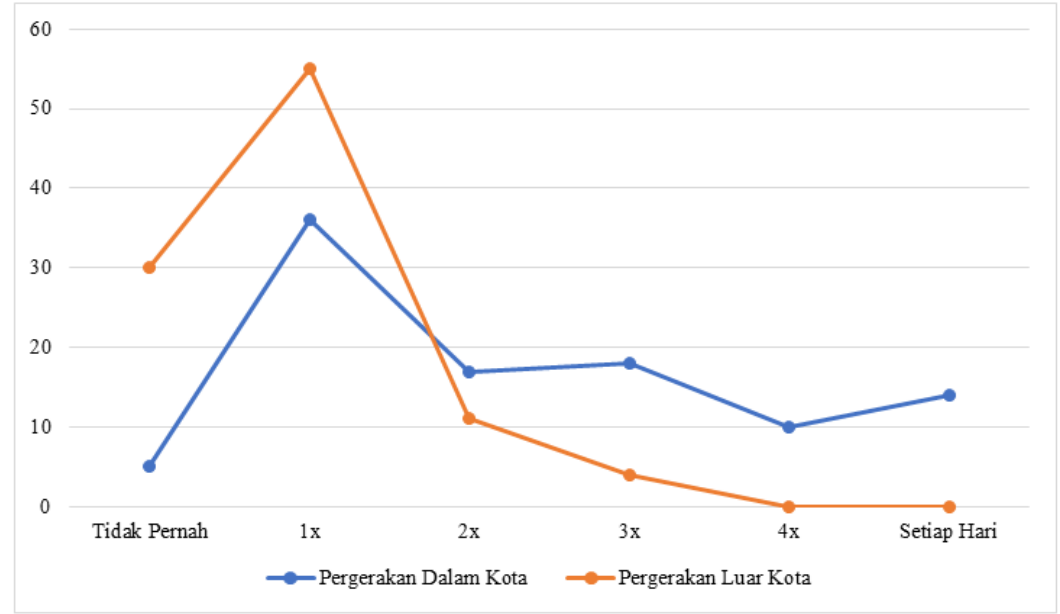

Gambar 4. Frekuensi mahasiswa melakukan perjalanan dalam dan luar kota selama pandemi

Selama pandemi Covid-19, perubahan signifikan terjadi dalam perjalanan jarak jauh yang membutuhkan mobilitas antar kota atau antar pulau. Motif pengguna moda transportasi umum melakukan perjalanan pada masa pandemi Covid-19 hanya karena urusan yang penting dan mendesak, yang didominasi karena urusan pekerjaan dan mendapat berita kematian dari keluarga. Sebagian besar penumpang memiliki kesadaran dalam mentaati protokol kesehatan yang telah diisyaratkan oleh Satgas Covid-19. Kebosanan juga menjadi motif terbesar kedua pada 
responden dikarenakan kebutuhan akan rekreasi pada masa pandemi ini mejadi sangat terbatas. Biasanya perjalanan jarak dekat disekitar kota tempat tinggal dapat mengurangi tingkat strees yang dialami mahasiswa.

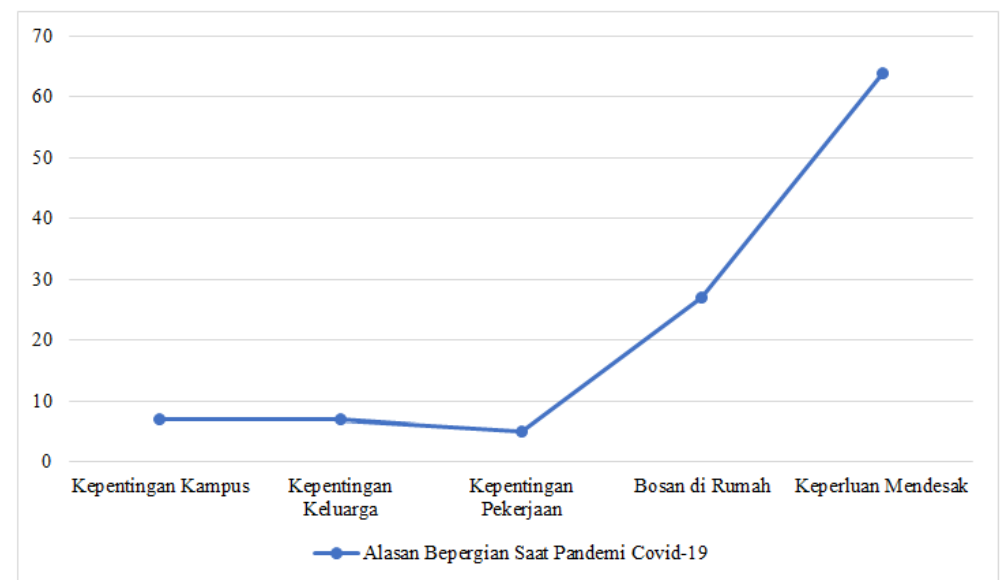

Gambar 3. Urgensi mahasiswa melakukan perjalanan selama pandemi

\section{Moda Split}

Ketika mengacu pada keselamatan perjalanan sebelum pandemi, masalah pertama yang terlintas dibenak kita adalah keselamatan berkendara atau keselamatan pribadi. Namun, wabah COVID-19 telah membawa perhatian kami ke parameter lain: risiko kontaminasi (Tarasi, 2021). Mobilitas dan khususnya angkutan umum mungkin berkontribusi pada penyebaran penyakit karena ruang tertutup dan beragamnya masyarakat yang menggunakannya. Oleh karena itu, sistem transportasi umum sangat rentan terhadap wabah penyakit (Edelson, 2011). Di sisi lain, kegiatan menjaga protokol kesehatan yang didorong oleh para ahli epidemiologi, yaitu setidaknya jarak $2 \mathrm{~m}$ antar individu, tidak sesuai dengan kondisi angkutan umum. Pada responden mahasiswa ditemukan bahwa mayoritas menggunakan kendaraan pribadi untuk bepergian saat pandemi ini, terutama pada perjalanan dalam kota. Namun kecenderungan menggunakan kendaraan umum saat bepergian jarak jauh juga masih diminati responden.

Selain itu, banyak penelitian menunjukkan dampak positif yang dramatis dari tindakan pembatasan kualitas udara dan pengurangan signifikan dalam polusi udara yang disebabkan penggunaan kendaraan bermotor yang minim. Selain itu, peningkatan moda perjalanan aktif (berjalan kaki, bersepeda) merupakan manfaat lain dari pandemi ini, mengingat selain ramah lingkungan, juga memiliki kecenderungan menjaga jarak sosial, yang saat ini sedang digemari (Kumari \& Toshniwal, 2020). kecenderungan tersebut sepertinya masih belum tampak signifikan pada responden mahasiswa, dimana mobilitas menggunakan kendaraan sepeda motor dan mobil masih menjadi pilihan utama dalam pandemi ini. Hal ini disebabkan karena kualitas jalur sepeda dan jalur pejalan kaki guna mendukung kegiatan mobiltas harian, belum dapat dikatakan berkualitas baik. Kedua moda transportasi ramah lingkungan ini hanya digunakan dengan tujuan rekreasional dan dalam jarak yang ralatif dekat saja.

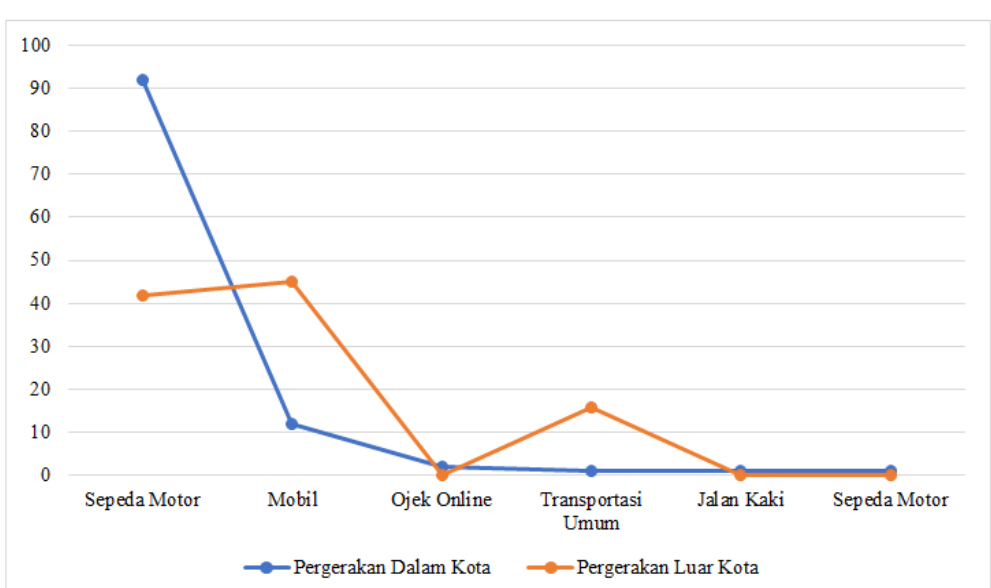

Gambar 4. Pilihan moda dalam melakukan perjalanan dalam kota dan luar kota selama pandemi 


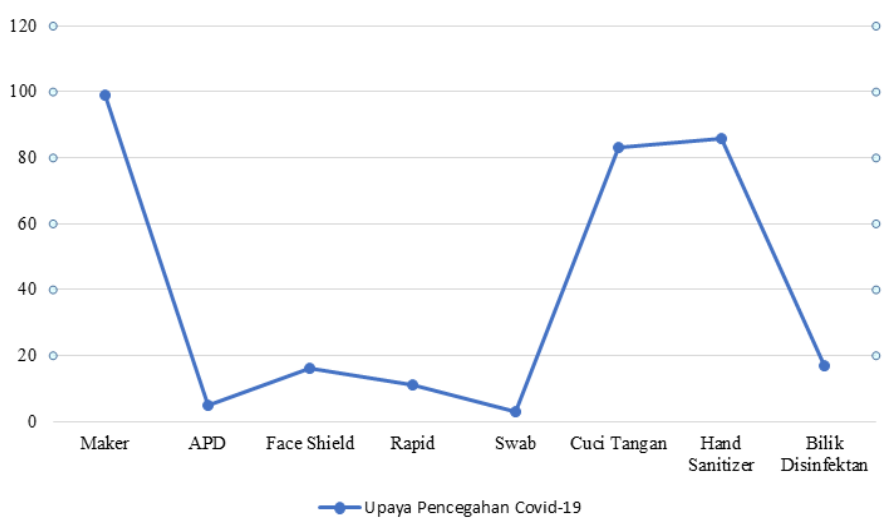

Gambar 5. Upaya pencegahan penularan Covid 19 saat melakukan perjalanan selama pandemi

Pembersihan dan disinfeksi yang sering pada armada angkutan umum, pembersih tangan, stiker lantai untuk menandai jarak yang memadai, adalah beberapa tindakan yang dapat meminimalkan risiko penularan dan melindungi pengendara dan karyawan (Tarasi, 2020). Demikian pula bagi responden, menggunakan APD seperti masker dan mencuci tangan menggunakan sanitizer disiapkan dalam melakukan perjalanan dalam kota. Sementara perjalanan luar kota, dengan menggunakan moda kereta api, dilakukan responden dengan mematuhi peraturan protokol kesehatan dengan menggunakan face shield dan melakukan rapid test sebelum keberangkatan.

\section{Trip Assignment}

Tantangan yang belum pernah terjadi sebelumnya yang disebabkan oleh pandemi COVID-19 menuntut tindakan tepat waktu. Namun, karena sifat pembuatan kebijakan yang kompleks, mungkin ada jeda antara waktu masalah dikenali dan waktu kebijakan berdampak pada sistem. Dengan menggunakan pola perjalanan sebagai indikator efektivitas kebijakan, lamanya kelambatan kebijakan dan besarnya dampak kebijakan pada sistem jalan raya, angkutan massal, dan mobilitas mikro diselidiki melalui studi kasus pergerakan mahasiswa selama pandemi di Propinsi Jawa Timur, dibatasi secara signifikan oleh COVID-19.

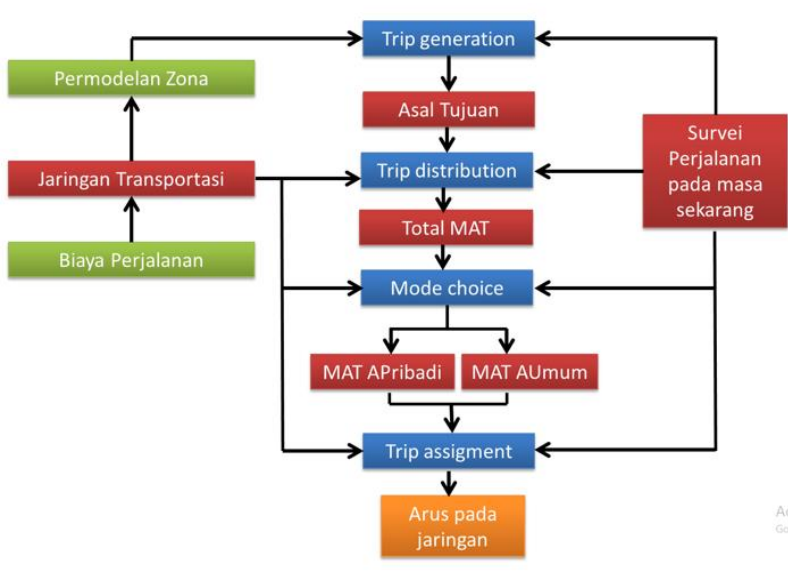

Model konvensional

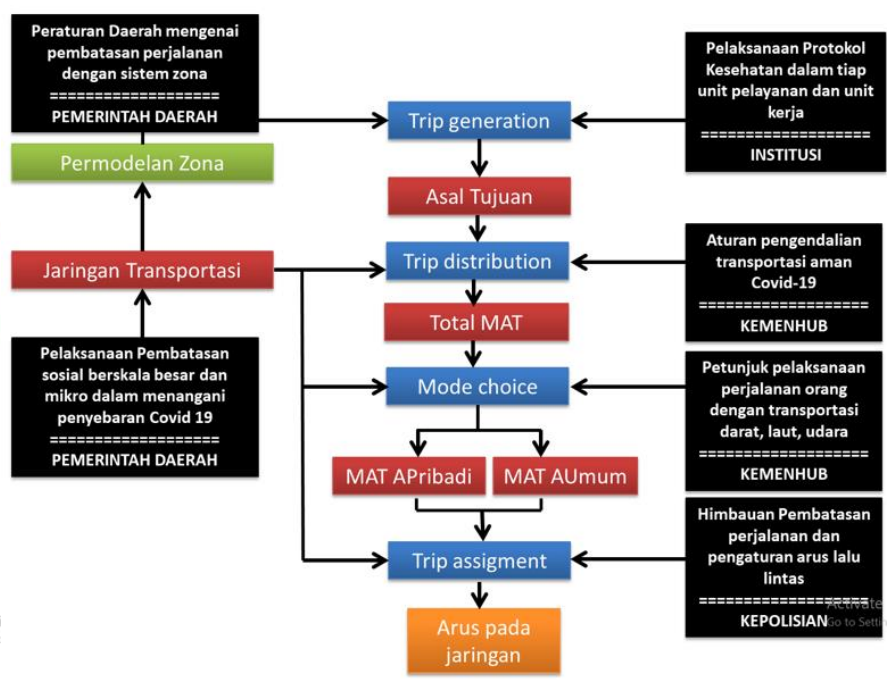

Rekayasa model selama pandemi

Gambar 6. Rekayasa model perencanaan transportasi selama pandemi Covid-19

Temuan kuantitatif menunjukkan bahwa Deklarasi Darurat Nasional seperti Peraturan Menteri Perhubungan republik Indonesia Nomor PM 18 Tahun 2020 Tentang Pengendalian Transportasi Dalam Rangka Pencegahan Penyebaran Corona Virus Disease 2019 (Covid-19) tidak memiliki dampak signifikan dalam mengurangi penularan Covid-19 di Jawa Timur. Sementara kebijakan Peraturan Gubernur Jawa Timur Nomor 18 Pasal 18 Tahun 2020 tentang Pembatasan Penggunaan Moda Transportasi Untuk Pergerakan Orang dan Barang menyebabkan banyak kegiatan harus dilakukan dari rumah dan membatasi mobilitas, sehingga menyebabkan kerugian ekonomi yang cukup besar. Karenanya, pertanyaan seperti "Bagaimana kita membuat orang tetap memastikan keselamatan mereka dalam melakukan perjalanan?" muncul dan menuntut solusi yang layak dan efisien. 
Besarnya dampak pandemi ini sangat bergantung pada kondisi kota/kabupaten dan karakteristik sosiodemografi kawasan, serta jenis sistem transportasi dan perjalanan. Sebagai contoh mobilitas di kota megapolitan Surabaya akan lebih kompleks jika dibandingkan dengan kabupaten seperti Kabupaten Lamongan. Demikian pula dengan kabupaten yang berbatasan langsung dengan ibu kota propinsi, seperti Kabupaten Sidoarjo dan Gresik yang terkoneksi dengan Kota Surabaya, mobilitas terjadi lebih signifikan karena kedua kota tersebut menyangga Kota Surabaya dalam berbagai sektor. Oleh karenanya, dalam merencanakan transportasi perlu dilakukan modifikasi dalam tiap tahapannya, dimana peraturan daerah perlu menjadi landasan. Bila Kota Surabaya telah mengeluarkan kebijakan Peraturan Walikota Surabaya Nomor 67 Tahun 2020 tentang Penerapan Protokol Kesehatan Dalam Rangka Pencegahan dan Memutus Mata Rantai Penyebaran Covid-19 di Kota Surabaya, maka perlu ada sinergitas dengan kebijakan kemenhub sebagai stakeholder ditingkat nasional dan juga kebijakan lalu lintas yang digawangi oleh kepolisian. Keempat tahapan perencanaan transportasi juga perlu dikaji lebih lanjut bila dalam pelaksanaannya meningkatkan infeksi covid-19 dan dapat dievaluasi ulang apakah perlu dicegah dalam tiap tahapannya.

\section{KESIMPULAN}

Kebijakan pembatasan mobilitas yang diberlakukan sebagai tanggapan terhadap meningkatnya penularan Covid19 membawa perubahan perilaku perjalanan masyarakat, baik tingkat global maupun lokal. Pengaruh pandemi COVID-19 sangat luar biasa dalam penyelenggaraan pendidikan tinggi terutama mobilitas mahasiswa. Berikut merupakan tahapan perencanaan transportasi yang dapat dilakukan saat pandemi covid-19 :

Trip generation

Metode pembelajaran di perguruan tinggi pada semua zona wajib dilaksanakan secara daring, juga membutuhkan kestabilan jaringan internet, sehingga mayoritas responden mahasiswa memilih untuk berada didekat area kampus, disamping pilihan tidak melakukan perjalanan dan hanya berada pada daerah asal mereka yang berbatas keterjangkauan jaringan internetnya.

\section{Trip distribution}

Selama pandemi Covid-19, motif pengguna moda transportasi umum melakukan perjalanan hanya karena urusan yang penting dan mendesak, yang didominasi karena urusan pekerjaan dan mendapat berita kematian dari keluarga. Sebagian besar penumpang memiliki kesadaran dalam mentaati protokol kesehatan yang telah diisyaratkan oleh Satgas Covid-19.

\section{Moda split}

Pada responden mahasiswa ditemukan bahwa mayoritas menggunakan kendaraan pribadi untuk bepergian saat pandemi ini, terutama pada perjalanan dalam kota. Namun kecenderungan menggunakan kendaraan umum saat bepergian jarak jauh juga masih diminati responden.

\section{Trip assignment}

Besarnya dampak pandemi ini sangat bergantung pada kondisi kota/kabupaten dan karakteristik sosiodemografi kawasan, serta jenis sistem transportasi dan perjalanan.

\section{DAFTAR PUSTAKA}

Agrawal, A., Udmale, S. S. \& Sambhe, V. (2018) Extended Four-Step Travel Demand Forecasting Model for Urban Planning. Information and Communication Technology for Sustainable Development, 191 - 198.

Ahmed, B. (2012) The Traditional Four Steps Transportation Modeling Using Simplified Transport Network: A Case Study of Dhaka City, Bangladesh, IJASETR Research Paper, 1, ISSN : 1839 - 7239.

Atbach, P. \& de Wit. H (2020). Post Pandemic Outlook for HE is Bleakest for the Poorest. University World News.

Basu, R. \& Ferreira, J. (2021) Sustainable mobility in auto-dominated Metro Boston: Challenges and opportunities post-COVID-19. Transport Policy, 103, 197-210.

Bian, Z., et. al. (2021) Time lag effects of COVID-19 policies on transportation systems: A comparative study of New York City and Seattle. Transportation Research Part A: Policy and Practice, 145, 269-283.

Bogoch, I. I, et. al. (2021) Potential for global spread of a novel coro navirus from China. Journal of Travel Medicine, $27,2$.

Cheung, C., Van Den Bos, P. \& Black, J. (2003) Urban trip distribution models: analysis of spatial residual errors and some implications for transportation policy and research. Journal of the Eastern Asia Society for Transportation Studies, 5, 2801 - 2816.

Edelson, P. \& Phypers, M. (2011) TB transmission on public transportation: a review of published studies and recommendations for contact tracing. Travel Medicine and Infectious Disease, 9 (1), 27-31.

Kadiyali, L. R. (2004) Traffic Engineering and Transport Planning, Delhi, Khanna Publishers, 2004. 
Katrakazas, C., Michelaraki, E., Sekadakis, M. \& Yannis, G. (2020) A descriptive analysis of the effect of the COVID19 pandemic on driving behavior and road safety. Transportation Research Interdisciplinary Perspectives, 7, 100186.

Koehl, A. (2020) Urban transport and COVID-19: challenges and prospects in low and middle-income countries. Cities \& Health, Published by Informa UK Limited, trading as Taylor \& Francis Group.

Kroesen, M. \& Chorus, C. (2020) A new perspective on the role of attitudes inexplaining travel behavior : A psychological network model. Transportation Research Part A, 133, 82 - 94.

Kutela, B. et. al. (2021) Exploring geographical distribution of transportation research themes related to COVID-19 using text network approach. Sustainable Cities and Society, 67, 102729.

Kumari, P. \& Toshniwal, D. (2020) Impact of Lockdown on Air Quality over Major Cities across the Globe during COVID-19 Pandemic. Urban Climate, 34,

Hal, M. C., et al. (2020) Pandemics, transformations and tourism: be careful what you wish for. Tourism Geographies, 22(3), 577-598

Mach (2021) Establishing a pre-COVID-19 baseline for surf tourism: Trip expenditure and attitudes, behaviors and willingness to pay for sustainability. Annals of Tourism Research Empirical Insights, 2(1), 100011.

Padmanabhan, V. et. al. (2021) COVID-19 effects on shared-biking in New York, Boston, and Chicago. Transportation Research Interdisciplinary Perspectives, 9, 100282.

Pepe, E., et. al. (2020) COVID-19 outbreak response, a dataset to assess mobility changes in Italy following national lockdown. ScientificData, 7, 230.

Politis, I. et. al. (2021) COVID-19 lockdown measures and travel behavior: The case of thessaloniki, Greece. Transportation Research Interdisciplinary Perspectives, 100345.

Tarasi, D., et al. (2021) Transportation in the Mediterranean during the COVID-19 pandemic era. Global Transitions, $3,55-71$

Teixeira, J. F \& Lopez, M. (2020) The link between bike sharing and subway use during the COVID-19 pandemic: The case-study of New York's Citi Bike. Transportation Research Interdisciplinary Perspectives, 6, 100166.

Tesar, M. (2020) Towards a post-Covid-19 “New Normality?”: Physical and social distancing, the move to online and higher education. Policy Future in Education, 18(5), 556-559.

Vingilis, E. et. al. (2020) Coronavirus disease 2019: What could be the effects on Road safety? Accident Analysis \& Prevention, 144, 105687.

Vos, J. (2020) The effect of COVID-19 and subsequent social distancing on travel behavior. Transportation Research Interdisciplinary Perspectives, 5, 100121.

Wang, C. et. al. (2020) Role of Urban Big Data in Travel Behavior Research. Transportation Research Record: Journal of the Transportation Research Board, 144, 105687.

Xiong, W. et. al. (2020) Impact of COVID-19 Pandemic on International Higher Education and Student Mobility: Student Perspectives from Mainland China and Hong Kong. Transportation. Centre for Global Higher Education working paper series, 